\title{
Model study to investigate the toxic interaction between glyphosate containing herbicide AMEGA and copper sulphate on pheasant embryos
}

\author{
Géza SZEMERÉDY ${ }^{1}$ - Imre PINTÉR ${ }^{1}$ - Rita SZABÓ ${ }^{1}$ - József LEHEL ${ }^{2}$ - Péter BUDAI ${ }^{1}$ \\ 1:University of Pannonia, Georgikon Faculty, Institute of Plant Protection, H-8360 Keszthely Deák F. utca. 16. \\ E-mail: tijsvanvervest@gmail.com \\ 2: University of Veterinary Medicine, Department of Food Hygiene, H-1078 Budapest, István út. 2. \\ E-mail: lehel.jozsef@univet.hu
}

Keywords: pheasant embryo, copper sulphate, interaction, combined toxic effects, herbicide

\section{Introduction}

The chemical plant protecting process is one of the most important polluting activities in the agricultural production. Sprayed pesticides and other xenobiotics, e.g. heavy metals, due to the agricultural activities during the plant protecting processes, can contaminate the ecosystem of a given habitat simultaneously. Therefore, the chemical load can occur as a complex problem, so the combined toxic effect, i.e. toxic interaction of at least two substances can expected and the components can modify the effect of each other. Recently, the examination of the combination of heavy metals and other chemicals gained significant ground in both avian (Fejes et al., 2001; Kertész, 2001) and mammalian (Institóris et al., 2001; Pecze et al., 2001) toxicology research studies. Furthermore, the interaction effects are examined not only in the field of ecotoxicology, but also in all other areas that deal with health care and chemical safety issues (Oskarsson, 1983; Danielsson et al., 1984; Speijers and Speijers, 2004).

\section{Materials and methods}

Pheasant eggs with good fertile potential (Szarvasi Vad-ker Kft., Hungary) were used in the experiment. The eggs based on their size and weight were divided into four homogenous groups (55 eggs in each), and were incubated in Ragus type table incubator (Vienna, Austria) ensuring the required temperature $\left(37-38^{\circ} \mathrm{C}\right)$, the relative humidity $(65-70 \%)$ and the daily rotation.

The eggs were dipped into the saline solution or emulsion of the test materials for 30 minutes on the first day of incubation. During the single and simultaneous administration copper sulphate (Reanal-Ker Ltd., Budapest) with a concentration of $0.01 \%$ and $2 \%$ of Amega glyphosate containing herbicide (Nufarm Hungary Ltd., 360 g/l) corresponding to that used in plant protection practice were applied. The control group was treated with avian physiological saline solution $(\mathrm{NaCl} 0.75 \%)$. All eggs and embryos were examined and processed on day 21 of incubation. During the processing rate of embryo mortality, body mass of embryos and type of developmental anomalies were registered.

\section{Results and discussion}

The average body weight of the embryos was significantly lower as compared to the control group in single administration of copper sulphate and Amega groups. The single and simultaneous administration of the test items increased the mortality of embryos as compared to the control. 
Developmental abnormalities were sporadically observed due to the single and concomitant administration. The results of the individual teratogenicity studies on copper sulphate in pheasant are in accordance with results of toxicity studies in other species. Depending on the dose, copper has embryotoxic potential and may cause developmental anomalies (Ferm, 1974; Várnagy and Budai, 1995).

\section{Conclusions}

Based on the results, there are presumably addition-type toxic interaction between copper sulphate and Amega herbicide that highly reduce the viability of the embryos.

\section{Acknowledgement}

The publication is supported by the EFOP-3.6.3-VEKOP-16-2017-00008 project. The project was co-financed by the European Union and the European Social Fund.

\section{References}

Danielsson, B.R.G., Oskarsson, A., Dencker, L. (1984): Placental transfer and fetal distribution of lead in mice after treatment with dithiocarbamates. Arch. Toxicol. 55: 27-33. DOI: https://doi.org/10.1007/bf00316582

Fejes, S., Várnagy, L., Budai, P., Takács, I. (2001): A réz-szulfát és a BI 58 EC interakciós vizsgálata házityúk embrión. TOX’2001 Konferencia. Eger. Absztraktok C2-4.

Ferm V. H., Hanlon D. P. (1974): Toxicity of copper salts in hamster embryonic development. Biology of Reproduction, 11. 97-101.

Institóris, L., Siroki, O., Dési, I. (2001): Kombinált cipermetrin $\mathrm{Hg}^{2+}$ és $\mathrm{As}^{3+}$ expozíció immuntoxikológiai vizsgálata patkányon. TOX’2001 Konferencia. Eger. Absztraktok C1-2. DOI: https://doi.org/10.1016/s15675769(01)00029-7

Kertész, V. (2001): Nehézfémek és PAH-vegyületek embrionális fejlődésre gyakorolt hatása madarakon. Doktori $(\mathrm{PhD})$ értekezés. SZIE MKK. Gödöllö.

Oskarsson, A. (1983): Redistribution and increased brain uptake of lead in rats after treatment with dethyldithiobarbamate. Arch. Toxicol. 6: 279-284. DOI: https://doi.org/10.1007/978-3-642-69083-9_52

Pecze, L., Papp, A., Nagymajtényi, L. (2001): Kombinált toxikus expozíció hatása az in vivo regisztrált hippokampális populációs spike-ra patkányban. TOX’2001 Konferencia. Eger. Absztraktok C1-4.

Speijers, G.J.A., Speijers, M.H.M. (2004): Combined toxic effects of mycotoxins. Toxicology Letters. 153: 9198. DOI: https://doi.org/10.1016/j.toxlet.2004.04.046

Várnagy, L., Budai, P. (1995): Agrochemical hygiene. Mezőgazda Publishing, Budapest. 45., 50-52., 64-65., $70-83$. 